ОСОБЛИВОСТІ РОЗВИТКУ РАДЯНСЬКОЇ ПСИХОЛОГІЇ НА ПОЧАТКУ СРСР

\title{
THE FEATURES OF THE PSYCHOLOGY DEVELOPMENT AT THE BEGINNING OF THE SOVIET STATE
}

УДК 159.9 (091) «191/193» DOI https://doi.org/10.32843/26635208.2020.15.12

\section{Погорільська Н.І.}

к.психол.н., доцент кафедри загальної психології

Київський національний університет імені Тараса Шевченка

\begin{abstract}
Розкриваються особливості розвитку вітчизняної психології на початку XX століття та вплив на ї̈ розвиток влади більшовиків і входження України до складу СРСР. Ці особливості представлено через розкриття життєвого та профресійного шляху Л.С. Виготського, Г.Г. Шпета, С.Л. Рубінштейна, $H$. Шпільрейна. У статті також розглядаються галузі та теми у психології, які виникають для вирішення задач державного значення (розробка ідей інженерної психології, теорії волі), а також озвучуються теорії та ідеї, які знищувались, оскільки не знаходили свого місця в радянському підході (етнопсихологія, психодіагностика тощо). Детальна увага прикута до теорії діяльності, ймовірних причин їі виникнення та ймовірних психологічних наслідків. На прикладі теорії діяльності та психотерапії обгрунтовано взаємозв'язок теорії та практики психології, а також ї̈ зв'язок з ідеологією радянської держави. На основі аналізу ідей та чінностей радянської ідеології розглядаються й особистісні особливості радянської людини, що були ссрормовані під їх впливом. Представлено напрями, погляди яких не входили в загальну матеріалістичну концепцію радянської психології, а тому знищувались або замовчувались (мантеїзм, психоаналіз). Визначено теорії та напрями розвитку психології, які майже з тієї ж причини не потрапляли до уваги фрахівців-психологів: теорія прийняття індивідуальних рішень, теорії мотивації тощо.

Ключові слова: психологія початку XX століття, радянська психологія, психологія діяльності, вплив радянської ідеології на психологію та на особистість, психологія як засіб радянської ідеології.
\end{abstract}

The article is devoted to the peculiarities of the development of psychology in the early twentieth century and the impact on its development of the Bolshevik government and the entry of Ukraine into the USSR are revealed. These features are presented through the disclosure of the life and professional path of L. Vygotsky, G. Shpet, S.L. Rubinstein, N. Spielrein. The article also considers the psychology's branches and topics that arise to solve problems of national importance (development of ideas of engineering psychology, the theory of will). The theories and ideas that were destroyed because they did not find their place in the Soviet approach (ethnopsychology, psychodiagnostics, etc.) is presented too. Detailed attention is paid to the theory of activity, the probable causes of its occurrence and the probable psychological consequences. The relationship between the theory and practice of psychology, as well as its connection with the ideology of the Soviet state, is substantiated on the example of the theory of activity and psychotherapy. Based on the analysis of ideas and values of Soviet ideology, the personal characteristics of the Soviet person, which were formed under their influence, are considered. The article is shown areas whose views were not included in the general materialist concept of Soviet psychology, and therefore destroyed or silenced (manteism, psychoanalysis). Theories and directions of psychology development are identified, which for almost the same reason did not come to the attention of psychologists: the theory of individual decision-making, the theory of motivation, and so on. Key words: beginning of the XX century's psychology, Soviet psychology, psychology of activity, influence of the Soviet ideology on psychology and on the person, psychology as agent of the Soviet ideology.
Тривалий час у вітчизняній історико-психологічній літературі XX століття була представлена лише одна лінія розвитку психології - та, яка була прописана ще за часів радянської психології або часу розпаду радянської держави. У матеріалах останніх років починають 3'являтись лінії побудови іншого вектора розвитку вітчизняної психології з урахуванням особливостей розвитку самої держави СРСР. Це роботи І.В. Данилюка, П.А. М'ясоїда, І.П. Шпичак тощо. Мета цієї статті - розглянути взаємозв'язок ідей СРСР та розвитку психології у першій половині $\mathrm{XX}$ століття.

3 позиції сьогодення вітчизняна психологія минулого століття $€$ «досить вразливою щодо критики через свою політичну ангажованість, ідеологічну зашореність і теоретичну односторонність та грубу нетерпимість до альтернативних тенденцій» [12, с. 200]. Як зазначає
С.С. Степанов, «у працях титулованих радянських психологів (а інших і не друкували: право на публікацію треба було заслужити довготривалою «вірнопідданістю») трапляються сентенції, які нагадують швидше ритуальні заклинання, ніж наукові судження» [12, с. 200].

Навіть найбільш знані психологи і ті, хто «заслужили» право публікуватись, у певні періоди свого життя стикались з різноманітними утисками з боку влади. Так, роботи психолога зі світовим ім'ям, чиї ідеї не втрачають своєї актуальності і до цього часу мають прихильників з різних країн світу, Л.С. Виготського фактично з 1936 року (у 1935 році за рік після його смерті учні надрукували декілька його робіт) і до 1956 року було заборонено друкувати, вилучались з бібліотек і знищувались [6, с. 242]. Ще навіть у 1981 році було заборонено проводити конференції, присвячені його 
творчості [6, с. 242]. Як зазначає К.Ю. Завершнева, загальні зауваження до його робіт: «ідеалізм, відсутність марксистсько-ленінського підходу і діалектики, методологічна неграмотність тощо» [6, с. 250].

Ще гірша доля чекала Г.Г. Шпета, учителя Л.С. Виготського. Ще під час навчання на філософському відділені Університету святого Володимира почав працювати у психологічному семінарі. Після переїзду до Москви у 1907 році працював у Московському університеті. У 1910-1911 роках стажувався у Геттінгемському університеті, де слухав лекції Е. Гуссерля. У 1920 році заснував перший у Радянському Союзі кабінет етнічної психології. У 1927 році опублікував «Вступ до етнічної психології». На його думку, предметом етнічної психології $є$ класифікація та систематизація типових колективних переживань (мова, міфи, звичаї тощо). Підкреслював, що найяскравіше ці переживання проявляються у вивченні цінностей. У 1923-1929 рр. був віце-президентом Російської художньої академії наук, де проводив дослідження в багатьох сферах науки, зокрема і етнопсихології. Після «чистки» та закриття Академії займався перекладом книг. У 1935 році через сфабриковану справу про антирадянськи налаштованих колишніх працівників Академії (справа німців-словарників) був заарештований та висланий до Томська, де був розстріляний у 1937 році через ще одну сфабриковану справу. Тривалий час (до 1989 року) вважалось, що він помер у 1940 році від запалення легень [14]. Конференції-вшанування його пам'яті стали проводитись з 1991 року. Як зазначає І.В. Данилюк, «починаючи з середини 30-х років XX століття психологи активно відхрещувалися від будь-яких спроб крос-культурних досліджень та будь-яких інших етнопсихологічних досліджень, від самої постановки й обговорення етнопсихологічних проблем» [4, с. 134].

$\mathrm{He}$ оминув «невдоволення керівництва» держави і лауреат Сталінської премії (1942 р.), доктор педагогічних наук з психології (1940), член-кореспондент АН СРСР (1943 р.) С.Л. Рубінштейн. Його роботи багаторазово перевидавались за кордоном, проте в своїй країні з 1947 року його звільняли з усіх керівних посад, позбавляли права публікуватись. Його роботи фактично (окрім роботи «Вчення І.П. Павлова і проблеми психології», яка вийшла в 1952 р., проте вона реально $€$ самокритикою вченого, каяттям у недотриманні павлівської фізіологічної лінії психології) почали виходити вже після смерті Й. Сталіна у 1957 році [6].

На початку радянської влади активно працювали і представники психоаналізу. Особливо прихильним до цього напряму був Л.Д. Троцький. У травні 1918 р. був заснова- ний Інститут дитини, завданням якого стало всебічне вивчення і поширення знань про природу дитини та їі виховання в дошкільному віці [15, с. 432]. У 1922 р. за підтримки Главнауки та особисто Л.Д. Троцького і Н.К. Крупської було засноване Російське психоаналітичне товариство. Керівником товариства став І.Д. Єрмаков, секретарем - М.В. Вульф, а згодом О.Р. Лурія [15, с. 434]. 3 ослабленням влади Троцького психоаналітика потрапляє в опалу. За наказом наркома охорони здоров'я Семашко всі ці «психоаналітичні інститути і садки» закривають. І3 30-их рр. XX століття і десь до 80-их років психоаналіз був лише «буржуазною психологію», що, відповідно, означало і заборону.

Також забороняється і тестування у 30-х роках XX століття. К.К. Платонов [8] зазначає, що вже в першій половині XX ст. широке застосування тестів отримало форму тестування. Цей напрям Б.М. Теплов іронічно назвав «клерківською психологією»: спеціаліст-психологтільки вигадує тестиіпишедоних інструкцію, а застосовує їх і дає висновки про здібності досліджуваного клерк, який нічого не розуміє в психології, але акуратний і відповідальний» [8]. Тоді ж з'являються думки, що говорити про тестологію неправильно, тому що так можна стверджувати про існування і «анкетології» та «бесідології». Також причиною заборони могли стати і не зовсім втішні результати тестування рівня інтелекту певних осіб (наприклад, стверджують, що І.В. Сталін був незадоволений низьким тестовим балом сина Василя [11, с. 38]). Все це стало причиною відмови від тестів, а іноді і вираженої боязні тестування. Таке рішення, на нашу думку, значно пригальмувало розвиток психодіагностичних засобів на території держави.

Тотальної заборони зазнавали цілі підходи. Так, для психології кінця XIX століття притаманнийівідхідвідсутоматеріалістичного розуміння і зародження так званого «спіритуалістичного» [9, с. 5]. Розглядаючи різкі зміни, які відбуваються у людини під впливом навіювання, психологи кінця XIX століття доходять висновку, що $€$ ще дещо, окрім центральної та периферичної частин нервової систем, що може керувати біологічними, життєвими процесами. I ця сила не зводиться ні до сили уяви, ні до волі, ні до підсиленої уваги. Цю силу назвали мантеїзм. Схожими були ідеї медіумізму, прибічником якого був і Ю.Л. Охорович, приват-доцент психології Львівського університету, ініціатор першого Міжнародного психологічного конгресу 6-10 серпня 1889 р. [16, с. 270].

у Москві з метою вивчення мантеїзму було створено Руську спільноту експериментальної психології, на засіданнях якої обговорювалось, що «експериментальна психологія - це вивчення та спостереження таких явищ психіч- 
ного життя, які, з одного боку, дуже непостійні, можна навіть сказати капризні, і які водночас дуже складні, заплутані і вимагають дуже багатьох тонких умов, які не виконуються або не завжди проявляються в присутності великої кількості свідків» [9, с. 4]. До складу спільноти могли входити всі, хто цікавиться знаннями з психології людини та тварини, проте бути вибраним членом цієї спільноти могли бути лише ті, хто має диплом лікаря або кандидата природничих наук. «Там, де справа стосується дослідної психології, не можна обійтись без допомоги і компетенції лікаря» [9, с. 4].

Завдання тогочасної експериментальної психології вони вбачали в розумінні можливості нематеріальної передачі почуттів, думок, волі чи бажань від однієї людини іншій. Активно користувались гіпнозом як методом встановлення мантеїзму читання думок, тобто передавання їх на відстані, особливо без посередництва яких-небудь матеріальних чи зовнішніх впливів [9, с. 6]. Зазначається, що суттєвим моментом ефективності проведення дослідження $€$ настрій експериментаторів та досліджуваних. I цей настрій суттєво залежить від фізичного стану та від так званого «душевного розташування». Для експериментатора надзвичайно важливою $€$ віра чи невіра в успіх експерименту. Причому вже тоді зазначалось, що величезна віра в успіх може мати негативний ефект. «Тут необхідна не віра, як багато хто думає, і навіть не впевненість, а повна індиферентність, повна відсутність забобон і присутність мінімального бажання, щоб дослід був успішний [9, с. 7].

Також відзначається, що наявність декількох експериментаторів значно підвищуе ефективність проведення експерименту. А також вказується на попередній досвід участі досліджуваного як фактор, що може викривляти ефект експерименту. Оскільки таке спіритуальне тлумачення психології розходилось із загальним науковим підходом того часу, існування такої спільноти тривалий час ігнорувалось та критикувалось, а з часом про їх існування взагалі практично не залишилось і згадок.

Отже, можна констатувати, що першим (у часі становлення) етапом формування вітчизняної психології стала «чистка» і виховання кадрів.

Завершення Другої світової війни в середині XX століття, а також і спосіб перемоги у цій війні остаточно сформували вектори розвитку світового та радянського простору і визначили їх найважливіші пріоритети. Так, світовий простір характеризується підйомом демократичного руху та надання переваги інтересам особистості над інтересами суспільства. Конвенція ООН (1948р.) декларує необхідність «визнання гідності, яка властива всім членам людської сім'ї», «віри в основні права людини, в гідність і цінність людської особистості і в рівноправність чоловіків і жінок» тощо (Із всезагальної декларації прав людини).

Для країни, яка протистояла ворогові не якістю кадрів та військової техніки-зброї, а кількістю громадян, було цілком зрозуміло обрання пріоритетом колективу та колективного, а не індивідуального, особистого. Відповідно, затверджуються як аксіоми твердження, що «людина - це гвинтик системи», що «незамінних людей немає» тощо. Людина, як-то кажуть, «один у полі не воїн», тому важливим $€$ колектив. Саме у ньому і $є$ сила. Отже, якщо за кордоном задля надання допомоги кожній особистості активно розвиваються методи психотерапії, то на території нашої держави психологічне знання «прикладалось» лише до технічних пристроїв та звірів - найбільшого розвитку зазнали військова, інженерна та порівняльна психології.

Психотерапія у Радянському Союзі не розвивалась. Можливо через те, що майже всі сфери життя контролювались та визначались на державному рівні. I функції психолога і психотерапевта виконували трудові, комсомольські чи піонерські зібрання. Навіть любов визначалось як почуття, яке може і повинне контролюватись державою, конфлікт між особистою симпатією та обов'язком повинен був вирішуватись на користь обов'язку.

Проте були напрями та теорії, які отримали ретельне опрацювання. Так, розроблялись теорії діяльності та волі як психічного процесу для формування радянської особистості. Воля як психічний процес у західній загальній психології не є обов'язково представленою (у підручнику Psychology Peter Gray, який вже має сім перевидань, цей психічний процес відсутній. Також його немає у підручниках «Загальної психології» Д. Майєрса). Для опису вольових характеристик використовують терміни, які розкривають психологічні особливості: рішучість, наполегливість тощо.

Тотальне нав'язування праці проглядалось у всьому, зокрема і у психології. Тому найбільш розробленою темою психології радянського періоду була теорія провідної діяльності С.Л. Рубінштейна та О.М. Леонтьєва. Життя людини поділялось на три етапи відповідно до провідного виду діяльності: ігрова діяльність (дитинство), навчання (від школяра до студента) і готова до праці людина. «Праця стає потребою. Якщо у дореволюційного селянина праця була обтяжливим обов'язком, то у сучасного селянина - це така ж природна потреба, як і потреба в їжі, одягу і житлі. I саме в праці він бачить можливість самоствердитись» [5, с. 79]. Ідея вивчення праці і її розуміння як головної потреби людини також мало ідеологічний вплив і швидше всього навіялось з робіт 
К. Маркса та Ф. Енгельса. Вислів Ф. Енгельса, що «праця зробила з мавпи людину» Став крилатим у радянські часи.

Працювати повинні були всі, хто може. «Мир, труд, травень» - гасло для життя кожної людини Радянського Союзу. Розвивається ідея працевлаштування і осіб з обмеженими можливості, яких називали лише «інвалідами». Улітературіпредставлено визначеннятермінів: «інваліди - «це особи, які працюють за обмеженим часом, мають менше навантаження порівняно зі здоровими людьми, чи неспроможні працювати взагалі, а інвалідність - це довготривала чи постійна, повна чи часткова втрата працездатності внаслідок порушених функцій організму у зв'язку з хворобою, травмою чи дефектом розвитку» (І. Капська). Ідея можливості працевлаштування осіб з обмеженими можливостями, звісно, приносить позитивні можливості для самореалізації, матеріального забезпечення і, відповідно, самостійності особистості з порушеннями психофізичного розвитку. Проте дуже часто для держави це мало лише суто економічне наповнення: «правильна оцінка ступеня інвалідності, розробка тестів реабілітації на основі прогнозування відділених результатів лікування дадуть значний економічний ефект» [13, с. 55], «тимчасова непрацездатність у дітей залишає більший слід, а це відкладає відбиток на ще несформований, нестійкий характер дитини, відповідно, на формування особистості майбутньої працюючої людини» [13, с. 54].

Держава, яка будувала комунізм, повинна була бути бездоганною у всьому. Діти - майбутне нації повинні були бути здоровими і щасливими. Виняткам з правила ідеологи тогочасного суспільства знайшли своєрідне виправдання: «хворі діти народжуються в сім'ях алкоголіків, отже, діти розплачуються за гріхи батьків, і держава тут ні до чого». Така ідеологічна установка вирішила всі проблеми дитячої інвалідності, добре прижилась у суспільстві, сформувала суспільну думку і принесла значний економічний ефект. Чотири стіни стали єдиним виходом для дітей-інвалідів на багато десятиліть. Відповідно, ключова думка, яка переслідує батьків дитини-інваліда, - інвалід у сім'ї - це жах. Іншим варіантом, який пропонувала держава, був навчальний заклад інтернатного типу, переважно закритий. Так, у СРСР було створено спеціальні школи 9 типів, не враховуючи шкіл для дітей зі складними дефектами (сліпоглухонімота, розумова відсталість у разі сліпоти тощо). Всі спеціальні школи, окрім допоміжних для розумово відсталих, забезпечують учням за різні терміни навчання неповну середню чи середню освіту і професійну підготовку з виробничих чи сільськогосподарських спеціальностей [2, с. 60].
Відкривались не лише школи-інтернати для дітей з обмеженими можливостями. Щороку збільшувалась і кількість ясел, дитячих садків, шкіл-інтернатів, піонерських таборів тощо. I не лише для підвищення освіченості населення, а й для того, аби звільнити батьків від догляду за дітьми для ще більшого занурення їх у робочий процес: «дитячі заклади сприяють розподілу турботи про дітей між сім'єю та суспільством, і цим самим жінка звільняється від попередньої «прикутості» до дому й отримує реальну можливість поєднувати сімейні обов'язки з роботою і суспільною діяльністю» [1, с. 52-53]. У 1978 році більше 12 млн дітей дошкільного віку виховувались у яслях та садках, тоді як батьки працювали" [1, с. 49]. Надзвичайно модним був лозунг «Хто не працює, той не їсть», хоча насправді не діяв: велика кількість партійних апаратників займалась лише витрачанням того, що заробляла інша частина населення.

Інтерес до вивчення психологічних аспектів праці з'явився ще на початку XX століття. Проте, якіпопередньо зазначалось, психологія праці (спочатку психотехніка) по-різному розкривалась за кордоном і у молодій радянській державі. Так, у США розпочинаючи з досліджень Ф. Тейлора проводилось вивчення психологічних факторів працездатності людей. У радянській державі акцент більше змістився на оптимізацію виробничих умов і засобів праці (оптимізація робочого місця водіїв трамваїв і пілотів літака; удосконалення друкарської машинки з урахуванням часу тощо) та на психофізіологічні аспекти праці (втомленість, автоматизація трудових дій, професійний відбір тощо). Однак у жовтні 1934 року ці психотехнічні інституції були знищені, а причетні до їхньої роботи психологи арештовані чи страчені. Так, одного з найяскравіших розробників радянської психотехніки І.Н. Шпільрейна у 1935 році арештовано, а у грудні 1937 року розстріляно. Відродились ідеї психотехніки в ідеях психології праці та інженерній психології уже після Другої світової війни.

Щоб краще зрозуміти психологічні чинники підвищення продуктивності праці співробітників, зарубіжна психологія розробила велику кількість теорій мотивацій, кожна з яких розкривала свої особливості мотивування особистості і різних сферах її життя: Д. Аткінсона, Г. Мюррей, А. Маслоу, Дж. Холла тощо. Особлива роль у вітчизняній психології належить дослідженням, пов'язаним з розвитком уявленьпромотиваціюу роботахЛ.С. Виготського, О.М. Леонтьєва, В.І. Мясищева, С.Л. Рубінштейна, Д.Н. Узнадзе та ін. У дослідженнях цих учених значна увага приділялася проблемі детермінованості діяльності суб'єкта, вольовій регуляції суб'єкта діяльності тощо [7, с. 334]. у більш пізніх вітчизняних теоріях мотива- 
ції (ті, що розвивались у другій половині $\mathrm{XX}$ століття) поступово починає проглядатись не лише суб'єкт діяльності, а і особистість.

Згідно з літературними джерелами радянська людина значну частку вільного часу присвячувала «підвищенню культурного рівня, професійної кваліфікації, суспільній діяльності, читанню, самодіяльній творчості тощо» $[1$, c. 50]. Проте найкращим проведенням часу радянської людини була праця. Тому з'являються і відповідні нові форми життєдіяльності: комуністичні суботники, “ударничество», стаханівський рух, рух за комуністичну працю тощо. «Навіть за наявності матеріального добробуту більшість селян охоче виходять на будь-які роботи і дуже ображаються, якщо через будь-які причини бригадир у той чи інший день не наряджає на роботу, це сприймається як особиста образа» [5, с. 79].

Перші дослідження психологічного благополуччя в американській науці припадають на першу половину XX століття. Таких напрямів виділяють чотири (Волинець). I хоча жодна з теорій не виявилась спроможною відповісти на поставлені питання, проте практика вивчення факторів психологічного благополуччя міцно сформувала свої підвалини. На відміну від американської психології, де вивчалось розуміння поняття «благополуччя», пов'язаність із задоволенням, його тривалість тощо [3], для радянської людини рекомендувався аскетизм, який як особистісна риса радянської людини означав, що «ціллю її життя повинне бути лише благополуччя держави у разі мінімальної турботи про себе» [5, с. 199-200]. Звісно ж таки, спосіб та особливості життя партійної номенклатури приховувались та «не помічались». Так, Сибіль зазначає, що серед 1955 анкет респондентів проведеного дослідження немає жодної, в якій би до позитивних рис людини колгоспники віднесли б прагнення до збагачення... [11, с. 25]

Відповідно до цієї риси радянській людині варто було бути «безсрібником», їй особисто нічого не було потрібно. «Однією з рис психології сучасного колгоспника $€$ скромність. Він добровільно і чесно виконує свій обов'язок, не виставляє на показ свої досягнення» [11, с. 25].

Висновки 3 проведеного дослідження. Загалом, можна стверджувати, що, незважаючи на складні обмеження та перешкоди у розвитку радянської психології, вона всетаки розвивалась, будучи у тісному сплетенні з державою. 3 одного боку, держава жорстко регламентувала, кому працювати і говорити, а кому мовчати, а часом і взагалі не жити. I хоча багато даних не доступні або втрачені, проте можна прослідкувати й інші лінії розвитку психології у радянські часи. 3 іншого боку, запити практики стимулювали розвиток психології і забезпечували ґрунтовні знання у необхід- ній сфері. Подальшими нашими розвідками стануть дослідження особливостей розвитку наукових шкіл територіальної української психології - Харківської, Одеської, Київської та Львівської - з метою розуміння їх головних чинників становлення та розвитку та особливостей впливусистеми СРСРнаїхстановлення.

\section{ЛITЕРАТУРА:}

1. Бороноев А.О. Нравственно-психологическое единство образа жизни советского народа. Ленинград: Изд-во Ленинградскогоуниверситета, 1978. 104с.

2. Власова Т.А. Проблема преодолений отклонения в развитии детей. Вестник Академии медицинских наук СССР. 1972. № 4. С. 60-66.

3. Волинець Н.В. Теоретичний аналіз категорії «психологічне благополуччя особистості» у сучасній психологічній науці. Теорія і практика сучасної психології. 2017. № 1. С. 4-17.

4. Данилюк І.В. Етнічна психологія в Україні: становлення та розвиток. Міжнародний науковий форум: соціологія, психологія, педагогіка, менеджмент. 2009. Вип. 1. С. 131-145.

5. Зотова И.О. Особенности психологии крестьянства / И.О. Зотова, В.В. Новиков, Е.В. Шорохова. Москва : Наука, 1983. 168 с.

6. М'ясоїд П.А. Психологічне пізнання: історія, логіка, психологія. Київ : Либідь. 2016. 560 с.

7. Каньоса Н.Г. Мотивація як внутрішній чинник розвитку профресіоналізму особистості. Проблеми сучасної психології. 2012. Вип. 18. С. 333-344.

8. Платонов В.В. Занимательная психология. Москва : Мол. гвардия, 1988. 224 с.

9. Протоколы заседаний Русского общества экспериментальной психологии в 1891-1892 г. Москва : Тип.Кушнерева и Ко., 1895. 45 с.

10. Психодіагностика для студентів-соціологів / уклад. Ю.В. Кушнір; відпов. ред. Ю.В. Кушнір. Донецьк : КиЦ, 2012. 346 с.

11. Сибиль Н.А. Объективные условия и субъективные фракторы фрормирования социалистической психологии колхозного крестьянства западных областей Украинской ССР : автореферат диссертации на соискание ученой степени кандидата философских наук : 09.00.01 «Диалектический и исторический материализм». Львов, 1973. 29 с.

12. Степанов С. Популярная психологическая энциклопедия. Москва. Эксмо. 2003. 640 с.

13. Усоскина Р.Я. Инвалидность у детей и пути профилактики. Труды Рижского науч.-иследов. ин-та травматологии и ортопедии. 1971. Вып. 11. С. 54-55.

14. Шпет Г.Г. Большая советская энциклопедия. 3-е изд. Москва, 1978. Т. 29; Поливанов М.К. Судьба Шпета. Вопросы ффилософии. 1990. № 6; Шпет в Сибири: ссылка и гибель. Томск, 1995; Томск от А до Я. Краткая энциклопедия города. Томск, 2004. C. 422-423. URL: http://nkvd.tomsk.ru/researches/ passional/shpet-gustav-gustavovich/.

15. Шпичак І.П. Психоаналітичні ідеї в контексті радянської освітньої політики першої половини XX століття. Теоретико-методичні проблеми виховання дітей та учнівської молоді. 2014. Вип. 18(2). С. 431-437.

16. Stachowski R. Historia współczesnej myśli psychologicznej. Od Wundta do czasów najnowsczych. Warszawa. 2010. 320 s. 